\title{
Health profile and health insurance coverage among a defined rural population of Tumkur, Karnataka: A cross sectional study
}

\author{
Shwetha ${ }^{1}$, Ashok J' ${ }^{2}$ Ashiq R Mir ${ }^{3, *}$ \\ ${ }^{\mathbf{1}}$ Assistant Professor, Dept. of Community Medicine, Subbiah Medical College and Hospital, Shivamogga, Karnataka, ${ }^{2}$ Professor, \\ Dept. of Community Medicine, Sri Siddhartha medical College, Tumkur, Karnataka, ${ }^{3}$ SMO, World Health Organisation, \\ Hilalabad, Srinagar, India \\ *Corresponding author: \\ Email: leoashiq@gmail.com
}

\begin{abstract}
To study the health profile of the population under study 3 . To assess the health insurance coverage and utilization patterns in the study population.

Materials and Methods: It is a Cross - sectional study. This study was undertaken in the rural field practice area of Sri Siddhartha Medical College, Tumkur, Karnataka .Six villages were chosen randomly. Multi stage sampling method was used. Sampling units were households. Oral questionnaire was used to collect the data and physiological parameters were measured. Results: According to this study $80 \%$ were Hindus, $15 \%$ were Muslims, 5\% Christians.57\% of the families belonged to OBC (other backward castes). Average family size: $=3.5409$ (SD \pm 1.1861 ) Anaemia was present in $64.9 \%$ of the population. Major recent illness were URTI 53\%, head ache $12 \%$ and myalgia $9 \%$. Health insurance coverage is $20 \%$ in the study area.

Conclusion: The major illnesses in the population were anaemia $65 \%, 58 \%$ had dental caries, hypertension was $24 \%, 15 \%$ of them had diabetes mellitus. Health insurance coverage was around 20\%. Majority of the households( $93 \%$ ) were not aware about any health insurance schemes Only $13 \%$ of the insured were aware about the benefits of health insurance scheme and $8 \%$ of those who insured utilised the health insurance scheme benefits
\end{abstract}

Keywords: Health Profile, Universal Health Coverage, Rural Population, India, Health Insurance.

\section{Introduction}

Universal health coverage: The provision of, and access to, high-quality health services; and financial risk protection for people who need to use these services. ${ }^{1}$ The idea of universal health care (UHC) took root at the landmark Alma Ata Conference in 1978, where countries resolved to provide "Health for all". Universal access, it is a concept, which implies, the absence of geographical, financial, organizational, socio-cultural and gender based barriers to care In India health expenditure is largely out of pocket (78\%).Public expenditure on health is only $1.2 \% .^{2}$ The Government of India's social insurance schemes (Central Government Health Scheme and Employee State Insurance Scheme) and voluntary insurance schemes (Mediclaim provided through the four Government Insurance Company subsidiaries) are geared towards workers in the organised sector, who comprise not more than ten per cent of all workers Despite the progress, the gap between the present coverage of health services and universal health coverage remains large for many conditions of ill-health in many settings ${ }^{1}$. Through this study we want to assess where we stand in terms of universal health coverage.This study aims at assessing the present situation regarding the health profile and health insurance coverage in a defined rural population.

\section{Objectives}

1. To study socio demographic pattern of the population covered under the study.
2. To study the health profile of the population under study.

3. To assess the health insurance coverage and utilization pattern in the study population.

\section{Materials and Methods}

It is a Cross - sectional study. This study was undertaken in Tumkur district of Karnataka in India. The rural field practice area of Sri Siddhartha Medical College, Tumkur, consists of 23villages (total population of 8170 ). Six villages were chosen randomly from total of 23 villages. Six villages were Ballagere, Cholapura, Gangonahalli, Thimma Sandra,Vaderapura, Ballagere kaval.

\section{Sampling Method}

Multi stage sampling method was used. Sampling units were house holds

1. $1^{\text {st }}$ stage: 6 villages were selected by simple random sampling method.

2. $2^{\text {nd }}$ stage: Households were selected from list of selected six villages by probability proportion to size and simple random sampling.

\section{Sample Size}

Sample size was calculated by using the formula:

$\mathrm{n}=4 \mathrm{pq} / \mathrm{d}^{2}$

Where in

$\mathrm{n}=$ sample size

$z($ at $95 \%$ confidence interval $)=1.96 ; z^{2}=3.84$ 
$\mathrm{P}$ is proportion of utilization of services in rural area 65\% (according to the NFHS3 Data)

$\mathrm{q}$ is 1 -p i.e $35 \%$

$\mathrm{d}$ is allowable error $10 \%$ of $\mathrm{p}=6.5$

$\mathrm{n}=4 \times 65 \times 35 /(6.5)^{2}$

Estimated sample size -215 Households, rounded off to 250 House holds

$\mathrm{n}=\mathbf{2 5 0}$ house holds

Though the sample size was 250 households, data collection from 305 households was done.

Probability proportional to size was used for selecting the households from each village.

Example of PPS for each village was calculated by:

Total number of households in the village/ total number of households $x$ sample size

Ballagere: $208 / 581 \times 250=90$ house holds

Out of 208 houses 90 houses were chosen randomly using random number table. The number of houses to be visited for each village was calculated and houses were chosen randomly using random number table. Table 1 shows the description of villages selected and number of households from each village. Data was collected from 305 households.

Table 1: Distribution of the study population

\begin{tabular}{|l|l|c|c|}
\hline S. No & Village Total & & $\begin{array}{c}\text { Sampled } \\
\text { Houses }\end{array}$ \\
\hline 1 & Ballagere & 208 & 90 \\
\hline 2 & Cholapura & 89 & 38 \\
\hline 3 & Gangonahalli & 98 & 42 \\
\hline 4 & Thimmasandra & 66 & 28 \\
\hline 5 & Vaderapura & 95 & 42 \\
\hline 6 & Ballagerekaval & 25 & 10 \\
\hline
\end{tabular}

Primary data was collected by interview method using a semi structured questionnaire and examination of individuals present in the households was done during household survey.

All the selected households were included in the study. Households which were locked even after second visit. The study was conducted between November 2013 and April 2015.

Present study was approved by ethical committee of Sri Siddhartha medical college, Tumkur

\section{Steps followed in the study}

1. As a first step, selected houses were visited.

2. Written Informed consent was taken.

3. The questionnaire was used to collect the data.

4. Measurement of Blood pressure, height, weight of the individuals of the households who were present at the time of data collection (760) was done.

5. Examined for pallor, cataract, caries, Deafness.

6. The data thus collected was entered in the Microsoft excel spread sheet.

7. Data analysed using using Epi Info ${ }^{\mathrm{TM}}$ 7.1.1.14. Software.

\section{Results}

Data regarding the socio demography was collected using a semi structured questionnaire. Out of 305 households under the study $80 \%$ were Hindus, $15 \%$ were Muslims, 5\% Christians. 57\% of the families belonged to OBC (other backward castes) which included Vokkaligas which is a major caste, followed by general category $23 \%$, Scheduled caste $14 \%$ and Scheduled tribe $6 \%$. According to modified B. G. Prasad's classification ${ }^{3}$ (April 2013) Majority of them belonged to class $4(46 \%)$ and class $3(32 \%)$ followed by class $1(14 \%)$ and class $5(8 \%)$ as shown in Table 2 . Majority of them studied up to PUC (36\%) and illiterates were $27 \%$. Only $8 \%$ were graduates and $2 \%$ were Post -graduates. Average family size: Mean = $3.5409(\mathrm{SD} \pm 1.1861)$.

Table 2: Sociodemographic profile of the study population

\begin{tabular}{|c|c|c|}
\hline $\begin{array}{c}\text { Socio } \\
\text { Demography } \\
\end{array}$ & $\begin{array}{c}\text { Number of } \\
\text { House Holds } \\
\end{array}$ & Percentage \\
\hline \multicolumn{3}{|l|}{ Religion } \\
\hline Hindu & 244 & 80 \\
\hline Muslim & 46 & 15 \\
\hline Christians & 15 & 5 \\
\hline \multicolumn{3}{|l|}{ Caste } \\
\hline $\begin{array}{l}\text { Other Backward } \\
\text { Castes }\end{array}$ & 169 & 55 \\
\hline Scheduled Caste & 55 & 18 \\
\hline $\begin{array}{l}\text { General } \\
\text { Category }\end{array}$ & 54 & 18 \\
\hline Scheduled Tribe & 27 & 9 \\
\hline \multicolumn{3}{|l|}{$\begin{array}{l}\text { Socio Economic } \\
\text { Status* }\end{array}$} \\
\hline Class 1 & 3 & 1.5 \\
\hline Class 2 & 26 & 9 \\
\hline Class 3 & 98 & 32 \\
\hline Class 4 & 141 & 46 \\
\hline Class 5 & 25 & 8 \\
\hline \multicolumn{3}{|l|}{ EDUCATION } \\
\hline Illiterates & 82 & 27 \\
\hline Middle school & 45 & 15 \\
\hline High school & 32 & 12 \\
\hline Pre University & 109 & 36 \\
\hline Graduates & 25 & 6 \\
\hline Post graduates & 6 & 2 \\
\hline \multicolumn{3}{|l|}{ Type Of Family } \\
\hline Joint family & 188 & 61 \\
\hline Nuclear family & 60 & 20 \\
\hline Three generation & 57 & 19 \\
\hline
\end{tabular}

$(\mathrm{N}=$ Total number of House Holds Under the study= 305)

Data regarding unhealthy habits was collected. Tobacco usage (33\%) was the major form of unhealthy behaviour in the population followed by consumption of both alcohol and tobacco which is $18 \%$ (Table 3). 
Table 3: Health related behaviour

\begin{tabular}{|l|c|c|}
\hline $\begin{array}{l}\text { Health related } \\
\text { behaviour }\end{array}$ & $\begin{array}{c}\text { Any member of } \\
\text { the house hold }\end{array}$ & Percentage \\
\hline Tobacco & 101 & 33 \\
\hline $\begin{array}{l}\text { Alcohol }+ \\
\text { Tobacco }\end{array}$ & 54 & 18 \\
\hline Alcohol & 4 & 1 \\
\hline Total & 159 & 100 \\
\hline
\end{tabular}

Data was collected regarding the chronic illness in the family, here we used the definition of chronic disease as the one lasting 3 months or more, by the definition of the U.S. National centre for Health Statistics ${ }^{4}$. Major chronic diseases were as follows (Table 4 ). $65 \%$ of the family had anaemia and $58 \%$ had dental caries. Prevalence of hypertension was $24 \%$ and Diabetes type 2 was $15 \%$. Cataract and deafness were present in $2 \%$ of the household.

Table 4: Chronic illness in the house holds $(\mathrm{N}=305)$

\begin{tabular}{|l|c|c|}
\hline \multicolumn{1}{|c|}{ Disease } & $\begin{array}{c}\text { Any one member } \\
\text { of the family }\end{array}$ & Percentage \\
\hline Anemia & 198 & 65 \\
\hline Dental caries & 176 & 58 \\
\hline Hypertension & 72 & 24 \\
\hline $\begin{array}{l}\text { Diabetes } \\
\text { Mellitus type } \\
2\end{array}$ & 46 & 15 \\
\hline Cataract & 6 & \\
\hline Deafness & 6 & 2 \\
\hline
\end{tabular}

Data was collected regarding the recent illness, in this study we have defined it as minor illness in the study population in past six months which made them seek health care services. Major recent illness were URTI 53\%, head ache $12 \%$ and myalgia $9 \%$.Others conditions (10 other conditions) exacerbation of bronchial asthma, complications of diabetes mellitus like constituted $3 \%$ of the total recent illness as given in the Table 5. Other conditions were low back ache and pain abdomen.

Table 5: Recent illness in the study population

\begin{tabular}{|l|c|c|}
\hline Acute Illness & $\begin{array}{c}\text { Any person in } \\
\text { the family }\end{array}$ & Percentage \\
\hline URTI & 160 & 52.7 \\
\hline Headache & 37 & 11.1 \\
\hline Myalgia & 27 & 8.5 \\
\hline Weakness & 24 & 8 \\
\hline APD & 19 & 6 \\
\hline Joint pain & 12 & 4 \\
\hline LBA & 6 & 2 \\
\hline Pain Abdomen & 6 & 2 \\
\hline Others & 13 & 3 \\
\hline
\end{tabular}

Health insurance coverage: Only $20 \%$ of the study population were covered under some form of health insurance. More important finding is that $85 \%$ of those who are covered under some health insurance scheme were unaware of the benefits and the details of the health care service centres. Only $8 \%$ of them utilized the benefits of health insurance mainly for surgeries. Yeshaswini was the major health insurance scheme in this area which is a Co- operative society based health insurance scheme for agricultural, small scale industry workers like beedi rolling etc.

\section{Discussion}

Religion: In this study Out of 305 households under the study $80 \%$ were Hindus, $15 \%$ were Muslims, 5\% Christians which is similar to 2011 census where $83 \%$ of the population are Hindu, $12.2 \%$ are Muslim, 3.1\% are Christian, $0.8 \%$ are Jains, $0.7 \%$ are Buddhist, $<0.1 \%$ are Sikhs, and remaining belong to other religions. ${ }^{5}$ Caste / Tribe :In this study $50 \%$ of the family belonged to OBC (other backward castes) which included vokkaligas which is a major caste, followed by general category $30 \%$, Scheduled caste $12 \%$, Scheduled tribe $8 \%$ which is similar to 2011 Census of India ,where Scheduled Castes and Scheduled Tribes constitute $23.5 \%$ of Karnataka's 61 million population SCs constitute $16.5 \%$ of population. ${ }^{5}$

Educational status: In this study, the majority were studied up to Pre University College $(36 \%)$ and followed by illiterates (27\%). Primary and middle school education was attained by $15 \%$ of them, $12 \%$ of them studied up to high school. Only $8 \%$ were graduates and $2 \%$ were Post -graduates. The findings are consistent with the current literacy rate of India is $74.04 \% .^{6}$

Mean house hold size: In this study the mean house hold size is Mean $=3.5409(\mathrm{SD} \pm 1.1861)$. Mean house hold size according to NFHS-3 in rural areas was 4. $9^{7}$.In the present study the major family type was joint family $62 \%, 20 \%$ belonged to nuclear family followed by three generation family which is $19 \%$. Nuclear families in the rural areas according to NFHS-3 is $59.3 \%$. In this study Tobacco usage was $33 \%$ mainly beedi, gutka and paan and $18 \%$ consumed both alcohol and tobacco. However in this study $50 \%$ of the study population didn't had any unhealthy practices which is similar to WHO data, according to the data $25 \%$ of the male and $5 \%$ of the females use tobacco and tobacco products and alcohol usage is present in $5 \%$ of the population. ${ }^{8}$

In this study anaemia was present in $64.9 \%$ of the population which is lower when compared to a study in India where up to $88 \%$ of pregnant and $74 \%$ of nonpregnant women are affected ${ }^{9}$.An estimated $47 \%$ of women of reproductive age in developing countries are anemic. ${ }^{10}$ According to NFHS3 data the prevalence anaemia among women ranged between $35-70 \%$ in different states in India.79.1\% of India's children between the ages of three and six, and $56.2 \%$ of married women in the age-group 15-49 were found to be 
anaemic in 2006. ${ }^{11}$ Deafness :In this study the deafness was present in $2 \%$ of the population. The prevalence of deafness in Southeast Asia ranges from $4.6 \%$ to $8.8 \%$. In India, 63 million people $(6.3 \%)$ suffer from significant auditory loss. ${ }^{12}$

Dental caries: In this study caries was present in 58\% of the study population. The prevalence of dental caries is approximately $60 \%-65 \%$ in India $1 .^{13,14}$

Cataract: In this study $2 \%$ of the population had cataract which is higher than the cataract prevalence is $1 \%$ in Indian population according to NPCB data. ${ }^{15}$ According to a study done in rural area prevalence of cataract alone was $12.10 \%$ in the whole population. ${ }^{16}$

Awareness about health insurance in our study was very low which is lower than in a study done by Patro et al only $22 \%$ of the study population were aware about the health insurance schemes. ${ }^{17}$ According to one more study by Rashmi et al the awareness about the health insurance was $64 \%$ in South Indian population ${ }^{18}$.

\section{Limitations of the study}

1. No confirmatory tests were used for the diagnosis of conditions like Anaemia, Deafness and other chronic illness

2. All members of the family were not present at the time of data collection in some of the households and hence could not be examined for the morbidity.

3. Recall bias

4. Social desirability bias

\section{Conclusion}

The major illnesses in the population were anaemia $65 \%, 58 \%$ had dental caries, hypertension was $24 \%$, $15 \%$ of them had diabetes mellitus. Health insurance coverage was around $20 \%$. Majority of the households( 93\%) were not aware about any health insurance schemes Only $13 \%$ of the insured were aware about the benefits of health insurance scheme and $8 \%$ of those who insured utilised the health insurance scheme benefit

\section{References}

1. World Health Organization. Research for universal health coverage, Geneva: WHO;2013.

2. Executive summary, high level expert group report on universal health coverage for India by 2022. 2012; The Lancet, Commission on Investing in Health.

3. Shankar R D, Arlappa N. An Updated Prasad's Socio Economic Status Classification for 2013 .Int J Res Dev Health. April 2013; vol 1(2). www.ijrdh.com.

4. Chronic illness- National health council. www.nationalhealthcouncil.org >Pdf_Files

5. Government of India. Census of India, The Registrar General \& Census Commissioner, India, New Delhi .2011-12.www.data.gov.in

6. Literacy rate of India- population census 2011. www.census.co.in / literary .php.2011 http://www.indiaonlinepages.com/population/literacyrate-in-india.html
7. Fact sheets, NFHS-3(2005-2006), National family health survey. www.rchiips.org/nfhs/nfhs3.shtml\#

8. World health organization. World health rankings, health profile of India, www.who.int

9. Sanjay Kumar Gupta, Sanjay S Agarwal, RitujaKaushal, Ambuj Jain, Vineet Kumar Gupta, NeerajKhare .Prevalence of Anemia among rural population living in and around of rural health and training center, Ratua Village of Madhya Pradesh.Muller J Med Sci Res [serial online] 2014 [cited 2015 Nov 17];5:15-8 Available from: http://www.mjmsr.net/text.asp?2014/5/1/15/ 128936

10. Rural realities, www.thehindu.com

11. M E Bentley and PL Griffith, The burden of anaemia among women in India, European Journal of Clinical Nutrition (2003) 57, 52-60 doi:10.1038/sj. ejcn.1601504

12. Garg S, Chada S and Agarwal AK, Deafness: burden, prevention and control in India, Natl Med J India. 2009 Mar-Apr; 22(2):79-81.

13. Shouri KL. Dental caries in Indian children. Indian J Med Res. 1941;29:709-22.

14. Ramchandran K, Rajan BP, Shanmungan S. Epidemiological studies of dental disorders in Tamilnadu population, prevalence of dental caries and periodontal diseases. J Indian Dent Assoc. 1973;45:65-70.[PubMed]

15. NPCB INDIA NEWSLETTER, OCTOBER DECEMBER 2011 www.npcb.nic.in

16. 16.G V S Murthy, Sanjeev K Gupta, Neena John, and Praveen Vashist Current status of cataract blindness and Vision 2020: The right to sight initiative in India.Indian J Ophthalmol. 2008 Nov-Dec; 56(6): 489-494

17. Patro Binod K, Anand K and Kapoor B.K (2004). Health Insurance: An Assessment of Community Perception and Willingness to Pay in a Rural Area, Unpublished Article.HIFCON.

18. B. Reshmi, N. Sreekumaran Nair, K.M. Sabu and B.Unnikrishnan, Awareness of Health insurance in south India - a community based study.www. Medind.nic.In/hab/t07/i3/habt07i3p177.pdf. 